\title{
Characterization of a molybdenum-reducing bacterium with the ability to degrade phenol, isolated in soils from Egypt
}

\author{
Yunus Ibrahim ${ }^{1}$, Mahmoud AbdEl-MongY ${ }^{2}$, MOHD ShUKRI ShUKOR ${ }^{3}$, \\ SOBRI HUSSEIN ${ }^{4}$, ANNA PICK KIONG LING ${ }^{5 *}$, MOHD YUNUS SHUKOR ${ }^{1,3}$ \\ ${ }^{1}$ Department of Biochemistry, Faculty of Biotechnology and Biomolecular Sciences, Universiti Putra Malaysia, Selangor, Malaysia \\ ${ }^{2}$ Microbial Biotechnology Department, Genetic Engineering and Biotechnology Institute, Sadat City University, Egypt \\ ${ }^{3}$ Snoc International Sdn Bhd, Negeri Sembilan, Malaysia \\ ${ }^{4}$ Malaysian Nuclear Agency, Agrotechnology and Bioscience Division, Bangi, Malaysia \\ ${ }^{5}$ International Medical University, Kuala Lumpur, Malaysia
}

\begin{abstract}
Polluted sites often contain both heavy metals and organic xenobiotic contaminants. This warrants the use of either a great number of bacterial degraders or bacteria having the ability to detoxify several toxicants simultaneously. In this research, the ability of a molybdenum-reducing (Mo-reducing) bacterium isolated from contaminated soil to decolorize various phenolics independent of Mo reduction was screened. Studies showed that this bacterium was able to grow on 4-nonylphenol and reduced molybdate to Mo-blue. The optimal condition for this activity was $\mathrm{pH}$ between 6.3 and 6.8 and temperature of $34^{\circ} \mathrm{C}$. Glucose proved to be the best electron donor for supporting molybdate reduction followed by galactose, fructose, and citrate in descending order. Other requirements included a phosphate concentration between $2.5 \mathrm{mM}$ and $7.5 \mathrm{mM}$ and a molybdate concentration between 20 and $30 \mathrm{mM}$. The absorption spectrum of the Mo-blue produced was similar to numerous previously described Mo-reducing bacteria, closely resembling a spectrum of the reduced phosphomolybdate. Mo reduction was inhibited by mercury (II), silver (I), copper (II), cadmium (II), and chromium (VI) at $2 \mathrm{ppm}$ by $79.6 \%, 64.2 \%, 51.3 \%, 28.1 \%$, and $25.0 \%$, respectively. The biochemical analysis resulted in a tentative identification of the bacterium as Pseudomonas aeruginosa strain Amr-11. The ability of this bacterium to detoxify Mo and grow on nonylphenol makes this bacterium an important tool for bioremediation.
\end{abstract}

Key words: bioremediation, electron donor, molybdenum, nonylphenol, phenol

\section{Introduction}

Polluted sites are often contaminated with both heavy metals and organic compounds. This requires the use of either a multitude of bacterial degraders specific for each toxicant or bacteria having the capacity to detoxify numerous toxicants simultaneously. Molybdenum is one of the essential heavy metals that is required at trace amounts as a cofactor for numerous enzymes while it is toxic to a variety of organisms at elevated levels (Ahmad Panahi et al., 2014). This metal has many applications in industries in which it can be used as an alloying agent, an automobile engine anti-freeze component, a component of corrosion resistant steel, or a lubricant in the form of Mo disulfide. The wide application of Mo in industry has resulted in several water pollutions all over the world, including the Tokyo Bay, the Tyrol in Austria, and the Black Sea, where the Mo level counts in hundreds of parts per million (Davis, 1991; Neunhäuserer et al., 2001). In addition, terrestrially, levels of Mo above the Maximum Permissible Limit have been found in sewage, posing a health hazard as some of the reclaimed water from sewage were used in agriculture in the 1970s (Lahann, 1976). The toxicity of Mo in inhibiting spermatogenesis and arresting embryogenesis in organisms such as catfish and mice at levels as low as several parts per million have been reported (Meeker et al.,

\footnotetext{
*Corresponding author: International Medical University (IMU), 126, Jalan Jalil Perkasa 19, Bukit Jalil, 57000 Kuala Lumpur, Malaysia; e-mail: anna_ling@imu.edu.my
} 
2008; Bi et al., 2013; Bi et al., 2013; Zhai et al., 2013; Zhang et al., 2013). Furthermore, Mo is very toxic to ruminants at levels of several parts per million, and cows are affected the most (Underwood, 1979). In addition to heavy metals, hydrocarbons in the form of oil, grease, and phenolics are ranked as the number one scheduled waste generated from industries (Achmadi, 1996). Other sources of pollutants are accidents. For instance, an accident causing the 533 ton Indonesian tanker MV Endah Lestari carrying 18 tons of diesel and 600 tons of phenol to capsize in 2001 polluted the coastal waters of Indonesia and Malaysia, killing thousands of fish and cockles reared in 85 offshore cages (Dahalan et al., 2014).

Phenol and phenolic compounds (Fig. 1) are not only toxic to humans but also to many other organisms as well (Gami et al., 2014). Toxicity is due to the hydrophobicity of those compounds and to a certain extent, the formation of phenoxyl radicals (Hansch et al., 2000). Nonylphenol (NP) is one of the major degradation products when nonylphenol ethoxylates (NPEs), widely used as non-ionic surfactants, are discharged into sewage treatment plants or directly released into natural ecosystems. Large amounts of NPEs are used globally and have resulted in the accumulation of NP in the environment. The half-lives of NP in the environment can be as long as 100 days, which, coupled with its toxicity and endocrine activity (Gu et al., 2010), makes NP a potential threat to human health and to the aquatic and terrestrial ecosystems. It was reported that $\mathrm{NP}$ at environmental levels of between $0.022 \mathrm{ng} / \mathrm{l}$ and $220 \mathrm{ng} / \mathrm{l}$ could affect cytokine secretion in human placenta (Bechi et al., 2006) making its removal a priority. At this level, bioremediation is the plausible option since chemical and physical methods are noneconomic and ineffective (Watanabe et al., 2012).

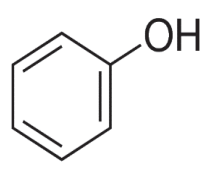

(A) Phenol

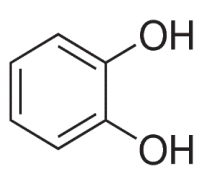

(B) Catechol

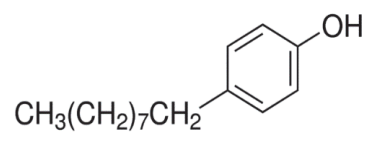

(C) 4-Nonylphenol
Fig. 1. The structure of some toxic phenolic compounds

Some microbes are able to degrade a variety of xenobiotic and detoxify heavy metals at the same time. Owing to their versatility, these microbes are in great demand in polluted sites where the presence of several conta- minants is the norm. Specific examples of their application include the reduction of chromate coupled with phenol biodegradation (Sun et al., 2011; Bhattacharya et al., 2014). In the present study, the ability of a novel Mo-reducing bacterium isolated from contaminated soil to grow on various phenolic compounds including phenol was screened. The study was conducted under static growth conditions, which were easy to obtain in a microplate environment where the oxygen concentration is between $0 \%$ and $10 \%$ of environmental oxygen (EO) whereas the EO under aerobic conditions is about $20 \%$. The microplate conditions mimic most of the bioremediation conditions, which are carried out in aquatic bodies or soils where the EO level is less than $\sim 20 \% \mathrm{EO}$. This paper reports on a novel Mo-reducing bacterium with the capacity to grow on NP isolated from contaminated soil. The characteristics of this bacterium would make it suitable for future bioremediation works involving both the heavy metal Mo and dye as organic contaminants.

\section{Materials and methods}

\section{Isolation of a molybdenum-reducing bacterium}

Soil samples were taken ( $5 \mathrm{~cm}$ deep from topsoil) from the grounds of the contaminated land in Sadat City, Egypt, in 2014. About $1 \mathrm{~g}$ of a soil sample was suspended in sterile tap water. A total of $0.1 \mathrm{ml}$ aliquot of the soil suspension was pipetted and spread onto agar of low phosphate media (LPM) (pH 7.0) and incubated for $48 \mathrm{~h}$ at room temperature. The composition of the LPM was as follows: glucose anhydrous (55 mM), $\left(\mathrm{NH}_{4}\right)_{2} \cdot \mathrm{SO}_{4}$ (22.7 mM), $\mathrm{MgSO}_{4} \cdot 7 \mathrm{H}_{2} \mathrm{O}(2.03 \mathrm{mM})$, yeast extract (0.5\%), $\mathrm{NaCl}(85.56 \mathrm{mM}), \mathrm{Na}_{2} \mathrm{MoO}_{4} \cdot 2 \mathrm{H}_{2} \mathrm{O}(10 \mathrm{mM})$ and $\mathrm{Na}_{2} \mathrm{HPO}_{4}(5 \mathrm{mM})$ (Yunus et al., 2009). The formation of blue colonies indicates molybdate reduction by Mo-reducing bacteria. A colony with most intense blue color was isolated and re-streaked on LPM to obtain a pure culture. Molybdenum reduction in liquid media (at $\mathrm{pH} 7.0$ ) was carried out in $100 \mathrm{ml}$ of the LPM. The bacterial culture was grown at room temperature for $48 \mathrm{~h}$ on an orbital shaker set at $120 \mathrm{rpm}$. To analyze the Mo blue (Mo-blue) absorption spectrum $1.0 \mathrm{ml}$ of the Mo-blue formed from the liquid culture above was centrifuged at $10,000 \times \mathrm{g}$ for $10 \mathrm{~min}$ at room temperature. Scanning of the supernatant was carried out from 400 to $900 \mathrm{~nm}$ using a UV-spectrophotometer (Shimadzu 1201). The LPM were utilized as the baseline correction. 


\section{Mo-reducing bacterium identification}

The bacterium was biochemically and phenotypically characterized using standard methods such as colony shape, gram staining, size and color on nutrient agar plate, motility, oxidase (24 h), ONPG (beta-galactosidase), catalase production ( $24 \mathrm{~h})$, ornithine decarboxylase (ODC), arginine dihydrolase $(\mathrm{ADH})$, lysine decarboxylase (LDC), nitrate reduction, Methyl red, indole production, Voges-Proskauer (VP), hydrogen sulfide $\left(\mathrm{H}_{2} \mathrm{~S}\right)$, acetate utilization, malonate utilization, citrate utilization (Simmons), esculin hydrolysis, tartrate (Jordans), gelatin hydrolysis, urea hydrolysis, deoxyribonuclease, lipase (corn oil), phenylalanine deaminase, gas production from glucose, and the production of acids from various sugars were carried out according to the Bergey's Manual of Determinative Bacteriology (Holt et al., 1994). Interpretation of the results was carried out via the ABIS online system (Costin and Ionut, 2015).

\section{Preparation of resting cells for molybdenum reduction characterization}

The characterization works such as the effects of $\mathrm{pH}$, temperature, phosphate, and molybdate concentrations to Mo-blue production were carried out utilizing resting cells in a microplate or microtiter format as previously developed. (Shukor and Shukor, 2014). Cells from a 11 overnight culture were grown in high phosphate media (HPM) at room temperature on orbital shaker (150 rpm) with the only difference between the LPM and HPM being the phosphate concentration that was fixed at $100 \mathrm{mM}$ for the HPM. Cells were harvested by centrifugation at $15,000 \times \mathrm{g}$ for $10 \mathrm{~min}$, and the pellet was washed several times to remove residual phosphate and was subsequently resuspended in $20 \mathrm{ml}$ of LPM (LPM without glucose) to $\mathrm{OD}_{600}$ of approximately 1.00 . In the LPM, the concentration of $5 \mathrm{mM}$ phosphate has been found optimal for all of the Mo-reducing bacteria isolated so far, and hence this concentration was used in this work. Higher concentrations were found to be strongly inhibitory to molybdate reduction (Campbell et al., 1985; Ghani et al., 1993; Shukor et al., 2007; Shukor et al., 2008a; Rahman et al., 2009; Shukor et al., 2009a; Yunus et al., 2009; Shukor et al., 2009b; Shukor et al., 2010a; Shukor et al., 2010b; Lim et al., 2012; Abo-Shakeer et al., 2013; Ahmad et al., 2013; Halmi et al., 2013; Othman et al., 2013; Khan et al., 2014). Then, $180 \mu$ l was pipetted into each well of a sterile microplate. An amount of $20 \mu \mathrm{l}$ of glucose from a stock solution was then added to each well to initiate Mo-blue production. A sealing tape that allows gas exchange (Corning $\AA$ microplate) was used for sealing the tape. The microplate was incubated at room temperature. At defined time points, the absorbance at $750 \mathrm{~nm}$ was read in a BioRad (Richmond, CA) Microtiter Plate reader (Model No. 680). The production of Mo-blue from the media in a microplate format was measured using the specific extinction coefficient of $11.69 / \mathrm{mM} / \mathrm{cm}$ at $750 \mathrm{~nm}$ as the maximum filter wavelength available for the microplate unit was $750 \mathrm{~nm}$ (Shukor et al., 2003).

\section{Effect of heavy metals on molybdenum reduction}

Seven heavy metals, namely, lead (II), arsenic (V), copper (II), mercury (II), silver (I), chromium (VI), and cadmium (II) were prepared from commercial salts or from Atomic Absorption Spectrometry standard solutions from MERCK. The bacterium was incubated with heavy metals, at various concentrations, in the microplate. The plate was incubated for $72 \mathrm{~h}$ at $30^{\circ} \mathrm{C}$. The amount of Mo-blue production was measured at $750 \mathrm{~nm}$ as before.

\section{Screening of molybdenum reduction and independent growth using phenolics}

The ability of phenolics such as phenol, 2,4-dinitrophenol, pentachlorophenol, 2-chlorophenol, 4-chlorophenol, catechol, salicylic acid, 4-nonylphenol, p-hydroxybenzoic acid, benzoate, and 2-napthol to support molybdenum reduction as electron donors was tested using the microplate as described above. In this case, glucose was replaced in the low phosphate medium with the phenolic compounds. The phenolic compounds, each at the final concentration of $200 \mathrm{mg} / \mathrm{l}$ and in a volume of $50 \mu$, were then mixed with $150 \mu$ of LPM (Arif et al., 2013). Then, $200 \mu \mathrm{l}$ of this preparation was placed into the microplate wells and mixed with $50 \mu$ of resting cell suspension. The microplate was incubated at room temperature for three days, and the amount of Mo-blue production was measured at $750 \mathrm{~nm}$ as before. The ability of the phenolics to support growth of this bacterium independent of molybdenum-reduction was tested using the LPM minus molybdate and replacing glucose with the phenolics at the final concentration of $200 \mathrm{mg} / \mathrm{l}$ in a volume of $50 \mu \mathrm{l}$. Then, $200 \mu \mathrm{l}$ of the media was added into the microplate wells with $50 \mu$ of resting cell suspension. The ingredients of the growth media (LPM) 
Table 1. Biochemical tests for Pseudomonas aeruginosa strain Amr-11

\begin{tabular}{l|c|c|c}
\hline \multicolumn{1}{c|}{ Motility } & + & Utilization of: & \\
\hline Hemolysis & + & L-Arabinose & $\mathrm{d}$ \\
\hline Growth at $4{ }^{\circ} \mathrm{C}$ & - & Citrate & + \\
\hline Growth at $41^{\circ} \mathrm{C}$ & + & Fructose & + \\
\hline Growth on MacConkey agar & + & Glucose & + \\
\hline Arginine dihydrolase (ADH) & + & meso-Inositol & - \\
\hline Alkaline phosphatase (PAL) & $\mathrm{d}$ & 2-Ketogluconate & + \\
\hline $\mathrm{H}_{2} \mathrm{~S}$ production & - & Mannose & - \\
\hline Indole production & - & Mannitol & + \\
\hline Nitrates reduction & + & Sorbitol & - \\
\hline Lecithinase & - & Sucrose & - \\
\hline Lysine decarboxylase (LDC) & - & Trehalose & - \\
\hline Ornithine decarboxylase (ODC) & - & Xylose & - \\
\hline ONPG (beta-galactosidase) & - & Starch hydrolysis & - \\
\hline Esculin hydrolysis & - & & \\
\hline Gelatin hydrolysis & + & & \\
\hline Starch hydrolysis & - & & \\
\hline Oxidase reaction & + & & \\
\hline
\end{tabular}

Note: + positive result, - negative result, $d$ indeterminate result

were as follows: $\left(\mathrm{NH}_{4}\right)_{2} \cdot \mathrm{SO}_{4}(22.7 \mathrm{mM}), \mathrm{NaNO}_{3}(0.2 \%)$, $\mathrm{MgSO}_{4} \cdot 7 \mathrm{H}_{2} \mathrm{O}(2.03 \mathrm{mM})$, yeast extract $(0.01 \%), \mathrm{NaCl}$ $(85.56 \mathrm{mM})$, and $\mathrm{Na}_{2} \mathrm{HPO}_{4}(50 \mathrm{mM})$. The media were adjusted to $\mathrm{pH} 7.0$ with $1 \mathrm{M} \mathrm{HCl}$. The increase of bacterial growth was measured at $600 \mathrm{~nm}$ after three days of incubation at room temperature.

\section{Statistical analysis}

Values are means \pm SE. Data analyses were carried out using the Graphpad Prism version 3.0 and Graphpad InStat version 3.05 available from www.graphpad.com.

\section{Results and discussion}

\section{Identification of Mo-reducing bacterium}

The bacterium was a short rod-shaped, motile, Gramnegative bacterium. It was identified by comparing the results of cultural, morphological, and various biochemical tests (Table 1) to the Bergey's Manual of Determinative Bacteriology (Holt et al., 1994) and using the ABIS online software (Costin and Ionut, 2015). The computational analyses suggested the bacterial identity as
Pseudomonas aeruginosa with a high homology score of $98 \%$ and accuracy score at $90 \%$. However, additional analyses, especially a molecular identification technique through comparison of the 16srRNA gene, are needed to characterize this species further. However, at this juncture, the bacterium is tentatively identified as $P$. aeruginosa strain Amr-11. Two Mo-reducing bacteria from this genus such as Pseudomonas sp. strain DRY2 (Shukor et al., 2010a) and the Antarctic bacterium Pseudomonas sp. strain DRY1 (Ahmad et al., 2013) have been reported previously. Bacterial strains from this genus have been known to degrade NP and NPEs (Yuan et al., 2004; Chakraborty and Dutta, 2006; Liu et al., 2006; Watanabe et al., 2012).

In the present work using this bacterium, a rapid and simple high throughput method involving microplate format was used to speed up the characterization works and obtain more data than in the ordinary shake-flask approach (Iyamu et al., 2008; Shukor and Shukor, 2014). The use of resting cells under static conditions to characterize Mo reduction in bacterium was initiated by Ghani et al., 1993. Resting cells have been used for studying 
heavy metal reduction such as selenate (Losi and Jr, 1997), chromate (Llovera et al., 1993), vanadate (Carpentier et al., 2005) reduction and xenobiotic biodegradation such as diesel (Auffret et al., 2014), SDS (Chaturvedi and Kumar, 2011), phenol (Sedighi and Vahabzadeh, 2014), amides (Raj et al., 2010), and pentachlorophenol (Steiert et al., 1987).

\section{Molybdenum absorbance spectrum}

The absorption spectrum of Mo-blue produced by P. aeruginosa strain Amr-11 exhibited a shoulder at approximately $700 \mathrm{~nm}$ and a maximum peak near the infra-red region of between 860 and $870 \mathrm{~nm}$ with a median at $865 \mathrm{~nm}$ (Fig. 2A). Mo-blue production was increased approximately in a linear fashion up to $24 \mathrm{~h}$ of incubation. Between 24 and 48 h, Mo-blue production appeared to be slowed down (Fig. 2B). The identification of the Mo-blue is not easily ascertained as it is complex in structure and has many species (Shukor et al., 2007). Basically, Mo-blue is a reduced product of two types of Mo complexes as follows: isopolymolybdate and heteropolymolybdate. It has been suggested by Campbell et al. (Campbell et al., 1985) that the Mo-blue observed after the reduction of Mo by $E$. coli $\mathrm{K} 12$ is a reduced form of phosphomolybdate, but these authors did not provide a plausible mechanism. The Mo-blue spectrum from the phosphate determination method normally showed a maximum absorption around 880 to $890 \mathrm{~nm}$ and a shoulder around 700 to $720 \mathrm{~nm}$ (Hori et al., 1988). We have shown previously that the entire Mo-blue spectra from other bacteria obey this requirement (Shukor et al., 2007). In this work, the result from the absorption spectrum clearly implies a similar spectrum, and thus confirms such hypothesis. Due to the complex structure of the compound, accurate identification of the phosphomolybdate species must be carried out using Nuclear Magnetic Resonance (NMR) and Electron Spin Resonance (ESR) (Chae et al., 1993). However, the spectrophotometric characterization of heteropolymolybdate species via analyzing the scanning spectroscopic profile is a less cumbersome and accepted method (Glenn and Crane, 1956; Sims, 1961; Kazansky and Fedotov, 1980; Yoshimura et al., 1986). Although the maximum absorption wavelength for Mo-blue was $865 \mathrm{~nm}$, the measurement at $750 \mathrm{~nm}$, although approximately $30 \%$ lower, was precise enough for routine monitoring of Mo-blue production as the absorbance value obtained have not inter-
A

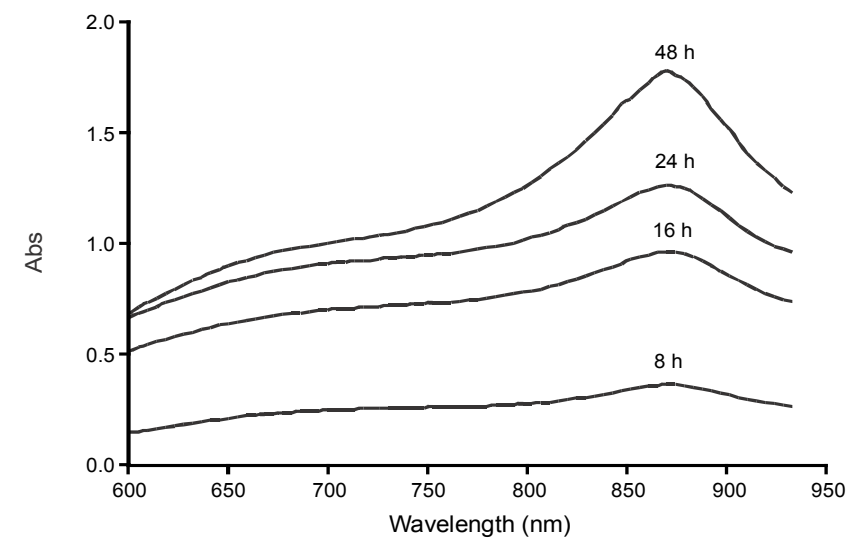

B

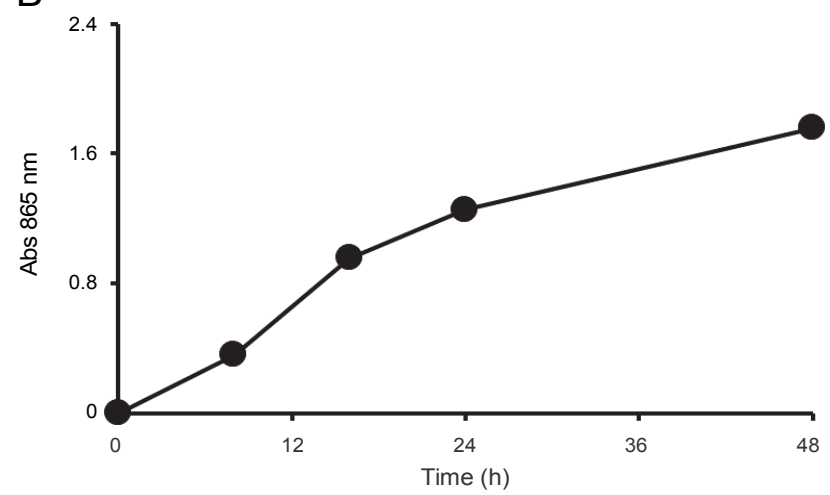

Fig. 2. A) Scanning absorption spectrum of Mo-blue from Pseudomonas aeruginosa strain Amr-11 at different time intervals, and B) profile of Mo-blue production over time measured at $865 \mathrm{~nm}$

fered with bacterial cell absorption of between 600 and $620 \mathrm{~nm}$ (Shukor and Shukor, 2014). Previous determination of Mo-blue production was carried out using wavelengths such as $710 \mathrm{~nm}$ (Ghani et al., 1993) and $820 \mathrm{~nm}$ (Campbell et al., 1985).

\section{Effect of $p H$ and temperature on molybdenum reduction}

$P$. aeruginosa strain Amr-11 was incubated at different $\mathrm{pH}$ ranging from 5.5 to 8.0 using Bis-Tris and Tris-Cl buffers $(20 \mathrm{mM})$. The optimum $\mathrm{pH}$ for molybdenum reduction was between 6.3 and 6.5 (Fig. 3). The effect of temperature (Fig. 4) was observed over a wide range of temperatures $\left(20-60^{\circ} \mathrm{C}\right)$ with an optimum temperature ranging from 25 to $37^{\circ} \mathrm{C}$. Temperatures higher than $37^{\circ} \mathrm{C}$ were strongly inhibitory to Mo-blue production from $P$. aeruginosa strain Amr-11.

Temperature and $\mathrm{pH}$ play important role in Mo reduction, and since this process is enzyme mediated, both parameters affect protein folding and enzyme activity causing the inhibition of Mo reduction. The optimum 


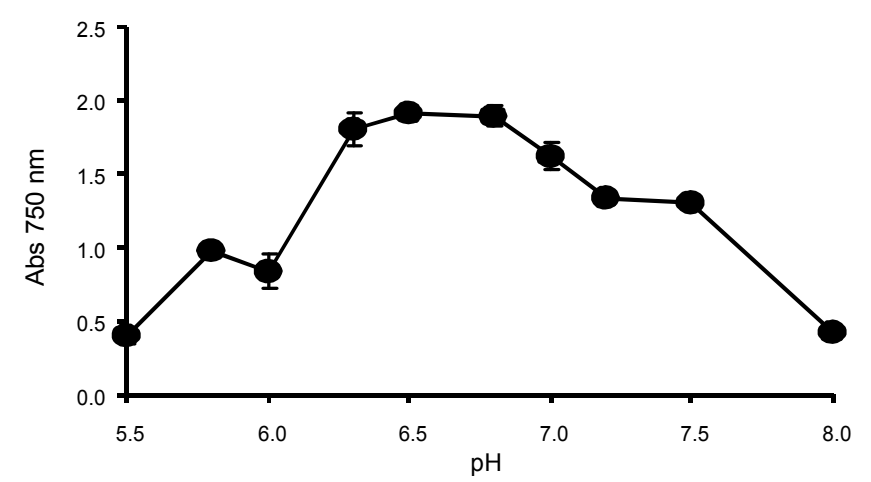

Fig. 3. Effect of $\mathrm{pH}$ on molybdenum reduction by Pseudomonas aeruginosa strain Amr-11. Resting cells of the bacterium were incubated in a microtiter plate under optimized conditions for $72 \mathrm{~h}$. Error bars represent mean $\pm \mathrm{SD}(n=3)$

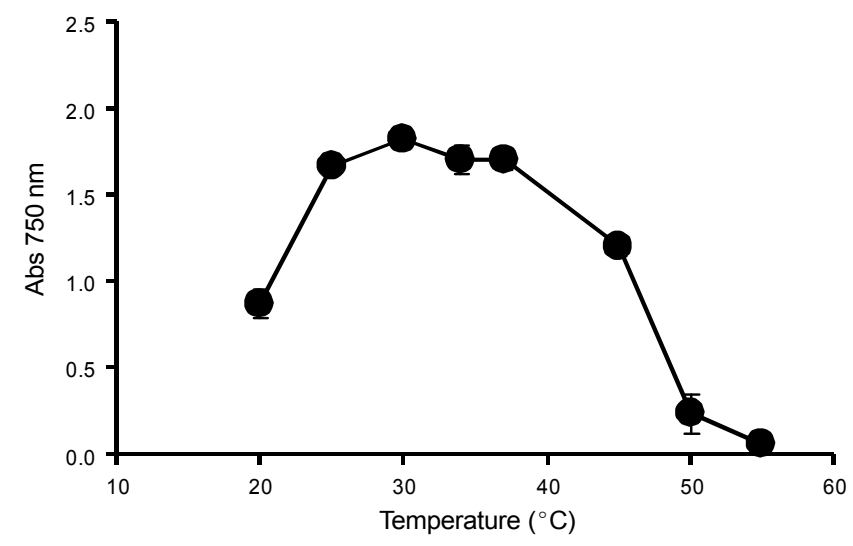

Fig. 4. Effect of temperature on molybdenum reduction by Pseudomonas aeruginosa strain Amr-11. Resting cells of the bacterium were incubated in a microtiter plate under optimized conditions for $72 \mathrm{~h}$. Error bars represent mean $\pm \mathrm{SD}(n=3)$

conditions for bioremediation would be found in a tropical country like Malaysia where average yearly temperature ranges from 25 to $35^{\circ} \mathrm{C}$ (Shukor et al., 2008a). Therefore, $P$. aeruginosa strain Amr-11 could be a candidate for soil bioremediation of Mo locally and in other tropical countries. The majority of the molybdenumreducing (Mo-reducing) bacteria show optimal temperatures supporting reduction between 25 and $37^{\circ} \mathrm{C}$ (Shukor et al., 2008a; Rahman et al., 2009; Yunus et al., 2009; Shukor et al., 2009b; Shukor et al., 2010a; Shukor et al., 2010b; Lim et al., 2012; Abo-Shakeer et al., 2013; Halmi et al., 2013; Othman et al., 2013; Khan et al., 2014; Shukor et al., 2014) as these bacteria are isolated from tropical soils. The only psychrotolerant Mo-reducing bacterium was isolated from Antarctica, and it shows optimal temperature supporting reduction between 15 and $20^{\circ} \mathrm{C}$ (Ahmad et al., 2013).
The optimal $\mathrm{pH}$ range exhibited by $P$. aeruginosa strain Amr-11 for supporting Mo reduction reflects the property of the bacterium as a neutrophile. The characteristics of neutrophiles include their ability to grow between $\mathrm{pH} 5.5$ and 8.0. An important observation regarding molybdenum reduction in bacteria is that a majority of the Mo-reducing bacteria exhibit optimal $\mathrm{pH}$ for molybdenum reduction under sub-neutral $\mathrm{pHs}$, with optimal pH ranging from $\mathrm{pH} 5.0$ to 7.0 (Campbell et al., 1985; Ghani et al., 1993; Shukor et al., 2008a; Rahman et al., 2009; Shukor et al., 2009a; Shukor et al., 2009b; Shukor et al., 2010a; Shukor et al., 2010b; Lim et al., 2012; Abo-Shakeer et al., 2013; Ahmad et al., 2013; Halmi et al., 2013; Othman et al., 2013; Khan et al., 2014; Shukor et al., 2014). It has been suggested previously that acidic $\mathrm{pH}$ plays an important role in the formation and stability of phosphomolybdate before it is being reduced to Mo-blue. Thus, optimal molybdenum reduction occurs at $\mathrm{pH}$ that is optimal for enzyme activity and at $\mathrm{pH}$ that maintains substrate stability (Shukor et al., 2007).

\section{Effect of electron donor on molybdate reduction}

Among the electron donors tested, glucose was the best electron donor for supporting molybdate reduction followed by galactose, fructose, and citrate in descending order (Fig. 5). Other carbon sources tested did not support Mo reduction. Previous works by Shukor et al. demonstrated that several of Mo-reducing bacteria such as Enterobacter cloacae strain 48 (Ghani et al., 1993), Serratia sp. strain Dr.Y5 (Rahman et al., 2009), S. marcescens strain Dr.Y9 (Yunus et al., 2009), and Serratia marcescens strain DRY6 (Shukor et al., 2008a) used sucrose as the best carbon source. Other Mo reducers such as Escherichia coli K12 (Campbell et al., 1985), Serratia sp. strain Dr.Y5 (Rahman et al., 2009), Pseudomonas sp. strain DRY2 (Shukor et al., 2010a), Pseudomonas sp. strain DRY1 (Ahmad et al., 2013), Enterobacter sp. strain Dr.Y13 (Shukor et al., 2009a), Acinetobacter calcoaceticus strain Dr.Y12 (Shukor et al., 2010b), Bacillus pumilus strain lbna (Abo-Shakeer et al., 2013), and BacilIus sp. strain A.rzi (Othman et al., 2013) prefer glucose as the carbon source while Klebsiella oxytoca strain hkeem prefers fructose (Lim et al., 2012). In the presence of carbon sources in the media, the bacteria could produce electron-donating substrates such as NADH and $\mathrm{NADPH}$ through metabolic pathways such as glycolysis, 


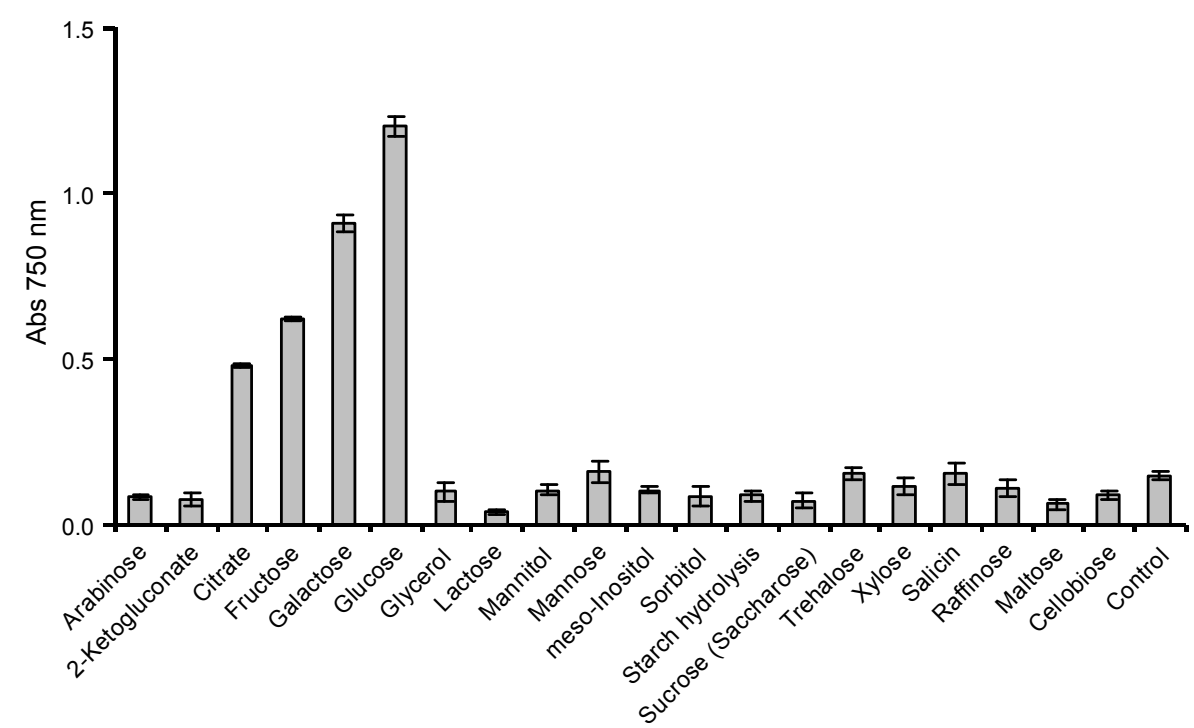

Fig. 5. Effect of different electron-donor sources ( $1 \% \mathrm{w} / \mathrm{v})$ on molybdenum reduction. Pseudomonas aeruginosa strain Amr-11 was grown in LPM containing $10 \mathrm{mM}$ molybdate and various electron donors. Resting cells of the bacterium were incubated in a microtiter plate under optimized conditions for $72 \mathrm{~h}$. Error bars represent mean $\pm \mathrm{SD}(n=3)$

Krebs cycle, and electron transport chain. Both $\mathrm{NADH}$ and NADPH serve as the electron donors for Mo-reducing enzymes (Shukor et al., 2008b; Shukor et al., 2014).

\section{Effect of phosphate and molybdate concentrations to molybdate reduction}

The determination of phosphate and molybdate concentrations supporting optimal Mo reduction is important because both anions have been shown to inhibit Moblue production in bacteria (Shukor et al., 2008a; Shukor et al., 2009a; Yunus et al., 2009; Shukor et al., 2009b; Shukor et al., 2010a; Shukor et al., 2010b; Lim et al., 2012; Ahmad et al., 2013; Othman et al., 2013; Shukor et al., 2014). The optimum concentration of phosphate has been found between 2.5 and $7.5 \mathrm{mM}$ with higher concentrations being strongly inhibitory to molybdenum reduction (Fig. 6). High phosphate was suggested to inhibit phosphomolybdate stability as the complex requires acidic conditions of which the higher the phosphate concentration the stronger buffering power of the phosphate buffer used. In addition, the phosphomolybdate complex itself is unstable in the presence of high phosphate through an unknown mechanism (Glenn and Crane, 1956; Sims, 1961; Shukor et al., 2000). All the Mo-reducing bacteria isolated so far tolerate phosphate concentrations not higher than $5 \mathrm{mM}$ for optimal reduction (Campbell et al., 1985; Ghani et al., 1993; Shukor et al., 2008a; Rahman et al., 2009; Shukor et al., 2009a;

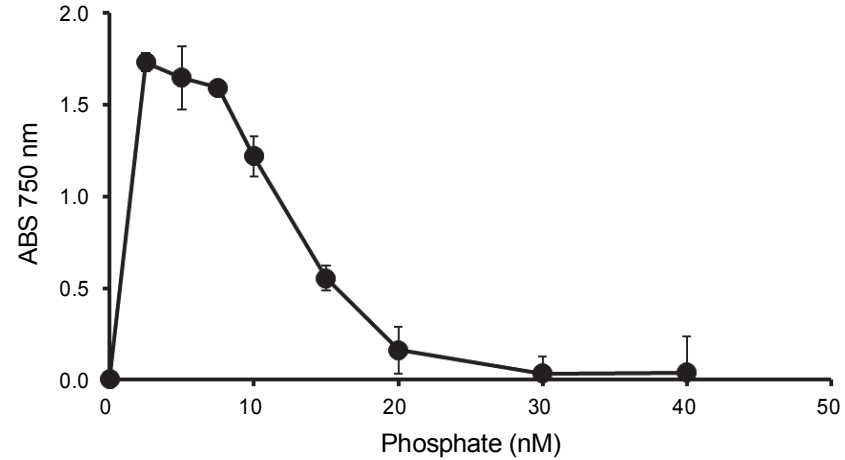

Fig. 6. The effect of phosphate concentration on molybdenum reduction by Pseudomonas aeruginosa strain Amr-11. Resting cells of the bacterium were incubated in a microtiter plate under optimized conditions for $72 \mathrm{~h}$. Error bars represent mean $\pm \mathrm{SD}(n=3)$

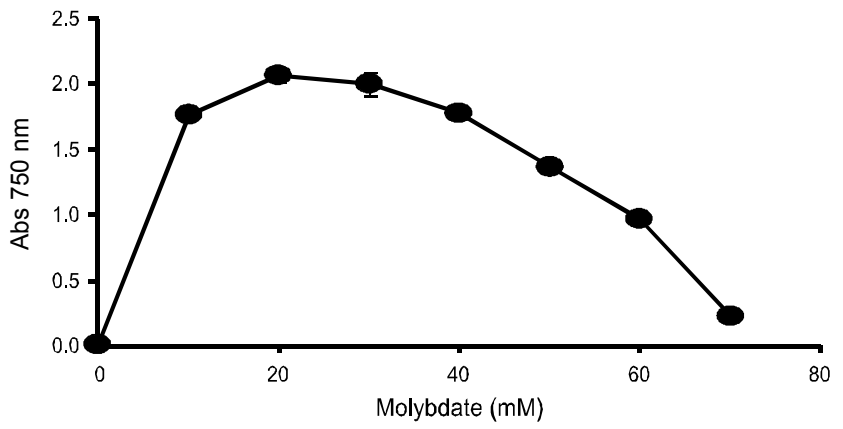

Fig. 7. The effect of molybdate concentration on molybdenum reduction by Pseudomonas aeruginosa strain Amr-11. Resting cells of the bacterium were incubated in a microtiter plate under optimized conditions for $72 \mathrm{~h}$. Error bars represent mean $\pm \mathrm{SD}(n=3)$ 


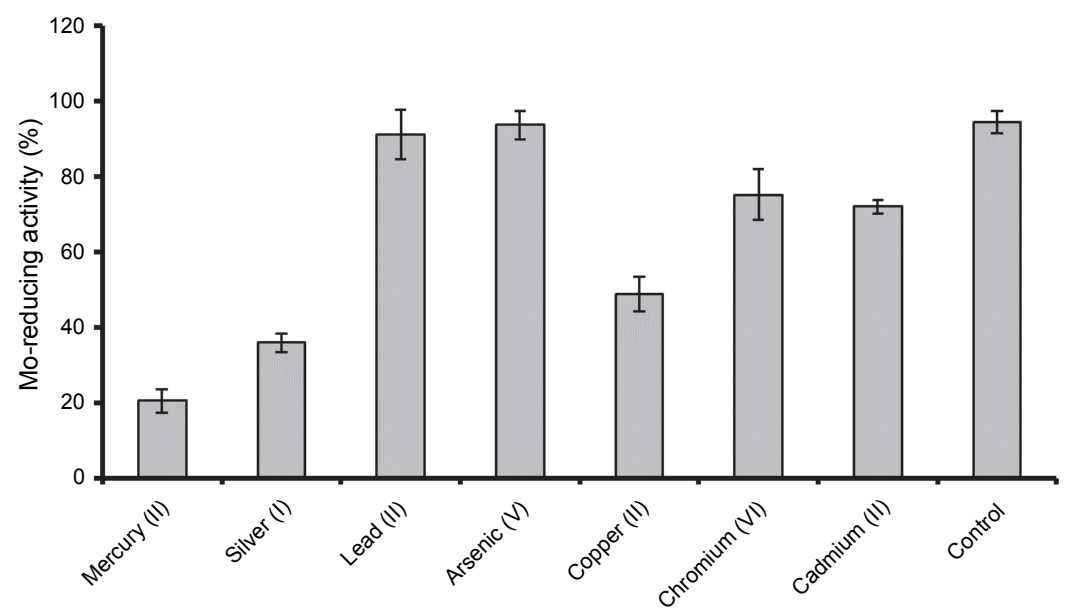

Fig. 8. The effect of metals on Mo-blue production by Pseudomonas aeruginosa strain Amr-11. Resting cells of the bacterium were incubated in a microtiter plate under optimized conditions for $72 \mathrm{~h}$. Error bars represent mean $\pm \operatorname{SD}(n=3)$

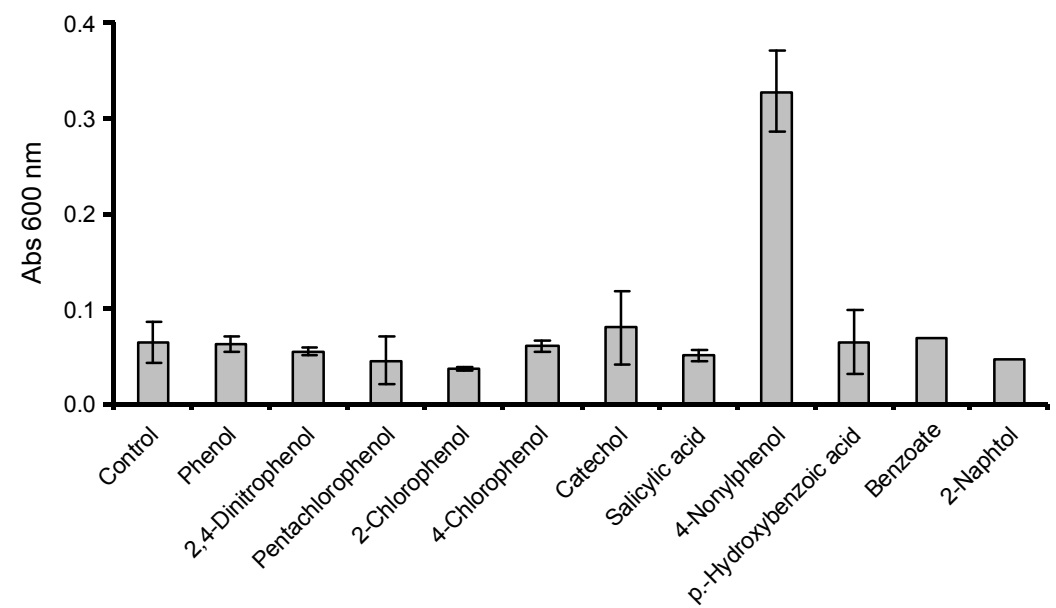

Fig. 9. Growth of Pseudomonas aeruginosa strain Amr-11 on phenolic compounds. Resting cells of the bacterium were incubated in a microtiter plate under optimized conditions for $72 \mathrm{~h}$. Error bars represent mean $\pm \mathrm{SD}(n=3)$

Table 2. Inhibition of Mo-reducing bacteria by heavy metals

\begin{tabular}{l|c|c}
\hline \multicolumn{1}{c|}{ Bacteria } & Heavy Metals that inhibit reduction & Author \\
\hline Bacillus pumilus strain lbna & $\mathrm{As}^{3+}, \mathrm{Pb}^{2+}, \mathrm{Zn}^{2+}, \mathrm{Cd}^{2+}, \mathrm{Cr}^{6+}, \mathrm{Hg}^{2+}, \mathrm{Cu}^{2+}$ & (Abo-Shakeer et al., 2013) \\
\hline Bacillus sp. strain A.rzi & $\mathrm{Cd}^{2+}, \mathrm{Cr}^{6+}, \mathrm{Cu}^{2+}, \mathrm{Ag}^{+}, \mathrm{Pb}^{2+}, \mathrm{Hg}^{2+} \mathrm{Co}^{2+}, \mathrm{Zn}^{2+}$ & (Othman et al., 2013) \\
\hline Serratia sp. strain Dr.Y8 & $\mathrm{Cr}, \mathrm{Cu}, \mathrm{Ag}, \mathrm{Hg}$ & (Shukor et al., 2009b) \\
\hline S. marcescens strain Dr.Y9 & $\mathrm{Cr}^{6+}, \mathrm{Cu}^{2+}, \mathrm{Ag}^{+}, \mathrm{Hg}^{2+}$ & (Yunus et al., 2009) \\
\hline Serratia sp. strain Dr.Y5 & $\mathrm{n} . \mathrm{a}$. & (Shukman et al., 2009) \\
\hline Pseudomonas sp. strain DRY2 & $\mathrm{Cr}^{6+}, \mathrm{Cu}^{2+}, \mathrm{Pb}^{2+}, \mathrm{Hg}^{2+}$ & (Ahmad et al., 2013) \\
\hline Pseudomonas sp. strain DRY1 & $\mathrm{Cd}^{2+}, \mathrm{Cr}^{6+}, \mathrm{Cu}^{2+}, \mathrm{Ag}^{+}, \mathrm{Pb}^{2+}, \mathrm{Hg}^{2+}$ & (Shukor et al., 2009a) \\
\hline Enterobacter sp. strain Dr.Y13 & $\mathrm{Cr}^{6+}, \mathrm{Cd}^{2+}, \mathrm{Cu}^{2+}, \mathrm{Ag}^{+}, \mathrm{Hg}^{2+}$ & (Shukor et al., 2010b) \\
\hline Acinetobacter calcoaceticus strain Dr.Y12 & $\mathrm{Cd}^{2+}, \mathrm{Cr}^{6+}, \mathrm{Cu}^{2+}, \mathrm{Pb}^{2+}, \mathrm{Hg}^{2+}$ & (Shukor et al., 2008a) \\
\hline Serratia marcescens strain DRY6 & $\mathrm{Cr}^{6+}, \mathrm{Cu}^{2+}, \mathrm{Hg}^{2+}$ & (Ghani et al., 1993) \\
\hline Enterobacter cloacae strain 48 & $\mathrm{Cr}^{6+}, \mathrm{Cu}^{2+}$ & (Campbell et al., 1985) \\
\hline Escherichia coli K12 & $\mathrm{Cr}^{6+}$ & (Lim et al., 2012) \\
\hline Klebsiella oxytoca strain hkeem & $\mathrm{Cu}^{2+}, \mathrm{Ag}^{+}, \mathrm{Hg}^{2+}$ & \\
\hline
\end{tabular}


Shukor et al., 2009b; Shukor et al., 2010a; Shukor et al., 2010b; Lim et al., 2012; Abo-Shakeer et al., 2013; Ahmad et al., 2013; Halmi et al., 2013; Othman et al., 2013; Khan et al., 2014; Shukor et al., 2014). Our studies on the effect of Mo concentration on Mo reduction showed that the newly isolated bacterium was able to reduce Mo at concentrations as high as $60 \mathrm{mM}$ but with reduced Mo-blue production. The optimal reduction range was at Mo concentrations between 20 and $30 \mathrm{mM}$ (Fig. 7). The reduction of Mo at such high concentrations, into an insoluble form, would allow the strain to decontaminate highly Mo-polluted sites. The lowest optimal concentration of Mo required for optimal reduction by bacteria reported so far is $15 \mathrm{mM}$ for Pseudomonas sp strain Dr.Y2 (Shukor et al., 2010a), while the highest was $80 \mathrm{mM}$ for E. coli K12 (Campbell et al., 1985) and Klebsiella oxytoca strain hkeem (Lim et al., 2012). Other Mo-reducing bacteria such as EC48 (Ghani et al., 1993), S. marcescens strain Dr.Y6 (Shukor et al., 2008a), S. marcescens. Dr.Y9 (Yunus et al., 2009), Pseudomonas sp. strain Dr.Y2 (Shukor et al., 2010a), Serratia sp. strain Dr.Y5 (Rahman et al., 2009), Enterobacter sp. strain Dr.Y13 (Shukor et al., 2009a), and Acinetobacter calcoaceticus (Shukor et al., 2010b) could produce optimal Mo-blue using the optimal molybdate concentrations of 50, 25, 55, 30, 30, 50, and $20 \mathrm{mM}$, respectively. In fact the highest concentration of Mo as a pollutant in the environment is around $2000 \mathrm{ppm}$, which is about $20 \mathrm{mM}$ (Runnells et al., 1976).

\section{Effect of heavy metals}

Molybdenum reduction was inhibited by mercury (II), silver (I), copper (II), cadmium (II), and chromium (VI) at $2 \mathrm{mg} / \mathrm{l}$ by $79.6 \%, 64.2 \%, 51.3 \%, 28.1 \%$, and $25.0 \%$, respectively (Fig. 8). The inhibition effects by other metal ions and heavy metals present a major problem for bioremediation. Therefore, it is important to screen for and isolate bacteria with as many metal-resistance capabilities as possible. As described previously (Shukor et al., 2002), mercury is a physiological inhibitor to molybdate reduction. A summary of the type of heavy metals that inhibited Mo-reducing bacteria showed that almost all of the reducers are inhibited by toxic heavy metals (Table 2). Heavy metals such as mercury, cadmium, silver, and copper usually target sulfhydryl groups of enzymes (Sugiura and Hirayama, 1976). Chromate is known to inhibit certain enzymes such as glucose oxi-

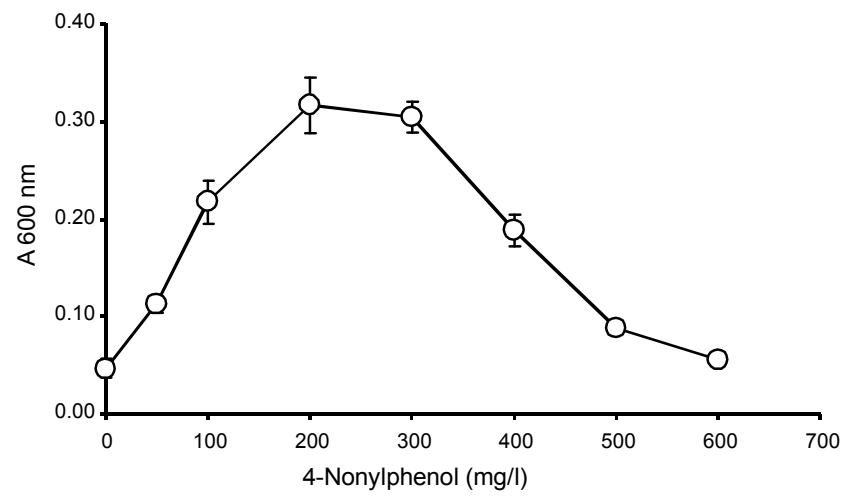

Fig. 10. Growth of Pseudomonas aeruginosa strain Amr-11 on 4-nonylphenol. Resting cells of the bacterium were incubated in a microtiter plate under optimized conditions for $72 \mathrm{~h}$. Error bars represent mean $\pm \mathrm{SD}(n=3)$

dase (Zeng et al., 2004) and enzymes of nitrogen metabolism in plants (Sangwan et al., 2014).

\section{Phenolics as electron-donor sources for molybdenum reduction and independent growth}

The screening for phenolics that could serve as electron donors supporting Mo reduction failed to give positive results. However, this bacterium was able to grow on the phenolic compound 4-nonylphenol (Fig. 9) with optimal growth efficiency between 200 and $300 \mathrm{mg} / \mathrm{l}$ (Fig. 10). Bacterial species and genera that have been reported to degrade NP and NPEs include Ochrobactrum sp., Staphylococcus sp., Achromobactersp., Alcaligenes sp. (Yu et al., 2012), Sphingomonas cloacae (Pluemsab et al., 2007), the genera Pseudomonas, Sphingomonas, Sphingobium, Cupriavidus, Ralstonia, Achromobacter, Staphylococcus (Gu et al., 2010), and Pseudomonas spp. (Yuan et al., 2004; Chakraborty and Dutta, 2006; Liu et al., 2006; Watanabe et al., 2012). The existence of multitude of bacteria with NP-degrading ability(ties) makes bioremediation the most useful method for NP degradation. However, very few bacteria have been reported to be able to degrade phenol and detoxify heavy metals. The ability of the bacterium described here, to do both, suggest that this bacterium may be very useful as a bioremediation agent in polluted sites co-contaminated with xenobiotic and heavy metals.

\section{Conclusions}

A local isolate of Mo-reducing bacterium with a novel ability to biodegrade the phenolic compound 4-nonylphenol has been isolated. This is the first time that 
a Mo-reducing bacterium with the ability to grow on this compound has been reported. The bacterium reduced molybdate to Mo-blue optimally in $\mathrm{pH}$ between 6.3 and 6.8 and at $34^{\circ} \mathrm{C}$. Glucose followed by galactose, fructose, and citrate (in descending order) has been found to be the best electron donors supporting molybdate reduction. Other requirements included a phosphate concentration between 2.5 and $7.5 \mathrm{mM}$ and a molybdate concentration between 20 and $30 \mathrm{mM}$. The absorption spectrum of the Mo-blue produced was similar to previously described Mo-reducing bacteria, closely resembling this of a reduced phosphomolybdate. Mo reduction by this bacterium was inhibited by mercury (II), silver (I), copper (II), cadmium (II), and chromium (VI). The ability of isolated bacterium to detoxify multiple toxicants is a sought-after property, and this makes the bacterium an important tool for bioremediation. Currently, work is underway to purify the Mo-reducing enzyme from this bacterium and to characterize 4-nonylphenol biodegradation properties in more detail.

\section{Acknowledgment}

This project was supported partially by funds from the company, Snoc International Sdn Bhd.

\section{References}

Abo-Shakeer L.K.A., Ahmad S.A., Shukor M.Y., Shamaan N.A., Syed M.A. (2013) Isolation and characterization of a molybdenum-reducing Bacillus pumilus strain Ibna. J. Environ. Microbiol. Toxicol. 1: 9-14.

Achmadi U.F. (1996) Public health implications of environmental pollution in urban Indonesia. Asia Pac. J. Clin. Nutr. 5: 141-144.

AhmadPanahi H., Hosseinzadeh M., Adinehlo H., Moniri E., Manoochehri m. (2014) Removal of molybdenum from environmental sample by adsorption using modified anilineformaldehyde with salicylic acid. World Appl. Sci. J. 30: 1892-1898.

Ahmad S.A., Shukor M.Y., Shamaan N.A., Mac Cormack W.P., Syed M.A. (2013) Molybdate reduction to molybdenum blue by an antarctic bacterium. BioMed Res. Int. doi: $10.1155 / 2013 / 871941$.

Arif N.M., Ahmad S.A., Syed M.A., Shukor M.Y. (2013) Isolation and characterization of a phenol-degrading Rhodococcus sp. strain AQ5NOL 2 KCTC 11961BP. J. Basic Microbiol. 53: 9-19.

Auffret M.D., Yergeau E., Labbé D., Fayolle-Guichard F., Greer C.W. (2014) Importance of Rhodococcus strains in a bacterial consortium degrading a mixture of hydrocarbons, gasoline, and diesel oil additives revealed by metatranscriptomic analysis. Appl. Microbiol. Biotechnol. 99(5): 2419-2430.
Bechi N., Ietta F., Romagnoli R., Focardi S., Corsi I., Buffi C., Paulesu L. (2006) Estrogen-like response to p-nonylphenol in human first trimester placenta and BeWo choriocarcinoma cells. Toxicol. Sci. 93: 75-81.

Bhattacharya A., Gupta A., Kaur A., Malik D. (2014) Efficacy of Acinetobacter sp. B9 for simultaneous removal of phenol and hexavalent chromium from co-contaminated system. Appl. Microbiol. Biotechnol. 98: 9829-9841.

Bi C.M., Zhang Y.L., Liu F.J., Zhou T.Z., Yang Z.J., Gao S.Y., Wang S.D., Chen X.L., Zhai X.W., Ma X.G. et al. (2013) The effect of molybdenum on the in vitro development of mouse preimplantation embryos. Syst. Biol. Reprod. Med. 59: 69-73.

Campbell A.M., Del Campillo-Campbell A., Villaret D.B. (1985) Molybdate reduction by Escherichia coli K-12 and its chl mutants. Proc. Natl. Acad. Sci. USA 82: 227-231.

Carpentier W., Smet L.D., Beeumen J.V., Brigé A. (2005) Respiration and growth of Shewanella oneidensis MR-1 using vanadate as the sole electron acceptor. J. Bacteriol. 187: 3293-3301.

Chae H.K., Klemperer W.G., Marquart T.A. (1993) High-nuclearity oxomolybdenum (V) complexes. Coord. Chem. Rev. 128: 209-224.

Chakraborty J., Dutta T.K. (2006) Isolation of a Pseudomonas sp. capable of utilizing 4-nonylphenol in the presence of phenol. J. Microbiol. Biotechnol. 16: 1740-1746.

Chaturvedi V., Kumar A. (2011) Diversity of culturable sodium dodecyl sulfate (SDS) degrading bacteria isolated from detergent contaminated ponds situated in Varanasi city, India. Int. Biodeterior. Biodegrad. 65: 961-971.

Costin S., Ionut S. (2015) ABIS online - bacterial identification software, http://www.tgw1916.net/bacteria_logare. html, database version: Bacillus 022012-2.10.

Dahalan F.A., Yunus I., Johari W.L.W., Shukor M.Y., Halmi M.I., Shamaan N.A. (2014) Growth kinetics of a dieseldegrading bacterial strain from petroleum-contaminated soil. J. Environ. Biol. 35: 399-406.

Davis G.K. (1991) Molybdenum. In: Metals and their Compounds in the Environment, Occurrence, Analysis and Biological Relevance. Ed. E. Merian. V.C.H. Weinheim, New York: 1089-1100.

Gami A.A., Shukor M.Y., Khalil K.A., Dahalan F.A., Khalid A., Ahmad S.A. (2014) Phenol and its toxicity. J. Environ. Microbiol. Toxicol. 2: 11-23.

Ghani B., Takai M., Hisham N.Z., Kishimoto N., Mohamed A.K., Mohamed Ismail A.K., Tano T., Sugio T. (1993) Isolation and characterization of a $\mathrm{Mo}^{6+}$-reducing bacterium. Appl. Environ. Microbiol. 59: 1176-1180.

Glenn J.L., Crane F.L. (1956) Studies on metalloflavoproteins. $V$. The action of silicomolybdate in the reduction of cytochrome c by aldehyde oxidase. Biochim. Biophys. Acta 22: 111-115.

Gu X., Zhang Y., Zhang J., Yang M., Tamaki H., Kamagata Y., Li D. (2010) Isolation of phylogenetically diverse nonylphenol ethoxylate-degrading bacteria and characterization of their corresponding biotransformation pathways. Chemosphere 80: 216-222. 
Halmi M.I.E., Zuhainis S.W., Yusof M.T., Shaharuddin N.A., Helmi W., Shukor Y., Syed M.A., Ahmad S.A. (2013) Hexavalent molybdenum reduction to Mo-blue by a Sodium-Dodecyl-Sulfate-degrading Klebsiella oxytoca strain DRY14. BioMed Res. Int. 2013: e384541. doi: 10.1155/2013/ 384541.

Hansch C., McKarns S.C., Smith C.J., Doolittle D.J. (2000) Comparative QSAR evidence for a free-radical mechanism of phenol-induced toxicity. Chem. Biol. Interact. 127: 6172 .

Holt J.G., Krieg N.R., Sneath P.H.A., Staley J.T., Williams S.T. (1994) Bergey's Manual of Determinative Bacteriology, 9th edn. Lippincott Williams \& Wilkins, Philadephia, USA.

Hori T., Sugiyama M., Himeno S. (1988) Direct spectrophotometric determination of sulfate ion based on the formation of a blue molybdosulphate complex. The Analyst. 113: $1639-1642$.

Iyamu E.W., Asakura T., Woods G.M. (2008) A colorimetric microplate assay method for high-throughput analysis of arginase activity in vitro. Anal. Biochem. 383: 332-334.

Kazansky L.P., Fedotov M.A. (1980) Phosphorus-31 and oxygen-17 N.M.R. evidence of trapped electrons in reduced 18-molybdodiphosphate(V), P2Mo18062 8- J. Chem. Soc. Chem. Commun. 644-646.

Khan A., Halmi M.I.E., Shukor M.Y. (2014) Isolation of Moreducing bacterium in soils from Pakistan. J. Environ. Microbiol. Toxicol. 2: 38-41.

Lahann R.W. (1976) Molybdenum hazard in land disposal of sewage sludge. Water Air Soil Pollut. 6: 3-8.

Lim H.K., Syed M.A., Shukor M.Y. (2012) Reduction of molybdate to molybdenum blue by Klebsiella sp. strain hkeem. J. Basic Microbiol. 52: 296-305.

Liu X., Tani A., Kimbara K., Kawai F. (2006) Metabolic pathway of xenoestrogenic short ethoxy chain-nonylphenol to nonylphenol by aerobic bacteria, Ensifer sp. strain AS08 and Pseudomonas sp. strain AS90. Appl. Microbiol. Biotechnol. 72: 552-559.

Llovera S., Bonet R., Simon-Pujol M.D., Congregado F. (1993) Chromate reduction by resting cells of Agrobacterium radiobacter EPS-916. Appl. Environ. Microbiol. 59: 35163518.

Losi M.E., Jr W.T.F. (1997) Reduction of selenium oxyanions by Enterobacter cloacae strain SLD1a-1: Reduction of selenate to selenite. Environ. Toxicol. Chem. 16: 1851-1858.

Meeker J.D., Rossano M.G., Protas B., Diamond M.P., Puscheck E., Daly D., Paneth N., Wirth J.J. (2008) Cadmium, lead, and other metals in relation to semen quality: $\mathrm{Hu}$ man evidence for molybdenum as a male reproductive toxicant. Environ. Health Perspect 116: 1473-1479.

Neunhäuserer C., Berreck M., Insam H. (2001) Remediation of soils contaminated with molybdenum using soil amendments and phytoremediation. Water Air Soil Pollut. 128: 85-96.

Othman A.R., Bakar N.A., Halmi M.I.E., Johari W.L.W., Ahmad S.A., Jirangon H., Syed M.A., Shukor M.Y. (2013) Kinetics of molybdenum reduction to molybdenum blue by Bacillus sp. strain A.rzi. BioMed Res. Int. doi: 10.1155/2013/ 371058.

Pluemsab W., Fukazawa Y., Furuike T., Nodasaka Y., Sakairi N. (2007) Cyclodextrin-linked alginate beads as supporting materials for Sphingomonas cloacae, a nonylphenol degrading bacteria. Bioresour Technol. 98: 2076-2081.

Rahman M.F.A., Shukor M.Y., Suhaili Z., Mustafa S., Shamaan N.A., Syed M.A. (2009) Reduction of Mo(VI) by the bacterium Serratia sp. strain DRY5. J. Environ. Biol. 30: 65-72.

Raj J., Prasad S., Sharma N.N., Bhalla T.C. (2010) Bioconversion of Acrylonitrile to Acrylamide using Polyacrylamide Entrapped Cells of Rhodococcus rhodochrous PA34. Folia Microbiol. (Praha) 55: 442-446.

Runnells D.D., Kaback D.S., Thurman E.M. (1976) Geochemistry and sampling of molybdenum in sediments, soils, and plants in Colorado. In: Molybdenum in the environment. Eds. W.R. Chappel, K.K. Peterson. Marcel and Dekker Inc., New York.

Sangwan P., Kumar V., Joshi U.N. (2014) Effect of chromium(VI) toxicity on enzymes of nitrogen metabolism in clusterbean (Cyamopsis tetragonoloba L.). Enzyme Res. 2014: 784036.

Sedighi M., Vahabzadeh F. (2014) Kinetic Modeling of cometabolic degradation of ethanethiol and phenol by Ralstonia eutropha. Biotechnol. Bioprocess Eng. 19: 239-249.

Shukor M.S., Shukor M.Y. (2014) A microplate format for characterizing the growth of molybdenum-reducing bacteria. J. Environ. Microbiol. Toxicol. 2: 42-44.

Shukor M.Y., Ahmad S.A., Nadzir M.M.M., Abdullah M.P., Shamaan N.A., Syed M.A. (2010a) Molybdate reduction by Pseudomonas sp. strain DRY2. J. Appl. Microbiol. 108: 2050-2058.

Shukor M.Y., Habib S.H.M., Rahman M.F.A., Jirangon H., Abdullah M.P., Shamaan N.A., Syed M.A. (2008a) Hexavalent molybdenum reduction to molybdenum blue by $S$. marcescens strain Dr. Y6. Appl. Biochem. Biotechnol. 149: 33-43.

Shukor M.Y., Halmi M.I.E., Rahman M.F.A., Shamaan N.A., Syed M.A. (2014) Molybdenum reduction to molybdenum blue in Serratia sp. strain DRY5 is catalyzed by a novel molybdenum-reducing enzyme. BioMed Res. Int. doi: $10.1155 / 2014 / 853084$.

Shukor M.Y., Lee C.H., Omar I., Karim M.I.A., Syed M.A., Shamaan N.A. (2003) Isolation and characterization of a molybdenum-reducing enzyme in Enterobacter cloacae strain 48. Pertanika J. Sci. Technol. 11: 261-272.

Shukor M.Y., Rahman M.F.A., Shamaan N.A., Lee C.H., Karim M.I., Syed M.A. (2008b) An improved enzyme assay for molybdenum-reducing activity in bacteria. Appl. Biochem. Biotechnol. 144: 293-300.

Shukor M.Y., Rahman M.F., Shamaan N.A., Syed M.A. (2009a) Reduction of molybdate to molybdenum blue by Enterobacter sp. strain Dr.Y13. J. Basic Microbiol. 49: S43-S54.

Shukor M.Y., Rahman M.F., Suhaili Z., Shamaan N.A., Syed M.A. (2009b) Bacterial reduction of hexavalent molyb- 
denum to molybdenum blue. World J. Microbiol. Biotechnol. 25: 1225-1234.

Shukor M.Y., Rahman M.F., Suhaili Z., Shamaan N.A., Syed M.A. (2010b) Hexavalent molybdenum reduction to $\mathrm{Mo}$ blue by Acinetobacter calcoaceticus. Folia Microbiol. (Praha) 55: 137-143.

Shukor M.Y., Shamaan N.A., Syed M.A., Lee C.H., Karim M.I.A. (2000) Characterization and quantification of molybdenum blue production in Enterobacter cloacae strain 48 using 12-molybdophosphate as the reference compound. Asia-Pac. J. Mol. Biol. Biotechnol. 8: 167-172.

Shukor M.Y., Syed M.A., Lee C.H., Karim M.I.A., Shamaan N.A. (2002) A method to distinguish between chemical and enzymatic reduction of molybdenum in Enterobacter cloacae strain 48. Malays. J. Biochem. 7: 71-72.

Shukor Y., Adam H., Ithnin K., Ibrahim Y., Shamaan N.A., Syed M.A. (2007) Molybdate reduction to molybdenum blue in microbe proceeds via a phosphomolybdate intermediate. J. Biol. Sci. 7: 1448-1452.

Sims R.P.A. (1961) Formation of heteropoly blue by some reduction procedures used in the micro-determination of phosphorus. Analyst. 86: 584-590.

Steiert J.G., Pignatello J.J., Crawford R.L. (1987) Degradation of chlorinated phenols by a pentachlorophenol-degrading bacterium. Appl. Environ. Microbiol. 53: 907-910.

Sugiura Y., Hirayama Y. (1976) Structural and electronic effects on complex formation of copper(II) and nickel(II) with sulfhydryl-containing peptides. Inorg. Chem. 15: 679682.

Sun J.Q., Xu L., Tang Y.Q., Chen F.M., Liu W.Q., Wu X.L. (2011) Degradation of pyridine by one Rhodococcus strain in the presence of chromium (VI) or phenol. J. Hazard Mater. 191: 62-68.

Underwood E.J. (1979) Environmental sources of heavy metals and their toxicity to man and animals. Prog. Water Technol. 11: 33-45.
Watanabe W., Hori Y., Nishimura S., Takagi A., Kikuchi M., Sawai J. (2012) Bacterial degradation and reduction in the estrogen activity of 4-nonylphenol. Biocontrol Sci. 17: 143147.

Yoshimura K., Ishii M., Tarutani T. (1986) Microdetermination of phosphate in water by gel-phase colorimetry with molybdenum blue. Anal. Chem. 58: 591-594.

Yuan S.Y., Yu C.H., Chang B.V. (2004) Biodegradation of nonylphenol in river sediment. Environ. Pollut. 127: 425430.

Yu D.U., Kim D.M., Chung Y.H., Lee Y.B., Kim Y.M. (2012) Isolation and characterization of nonylphenol-degrading bacteria. Fish. Aquat. Sci. 15: 91-97.

Yunus S.M., Hamim H.M., Anas O.M., Aripin S.N., Arif S.M. (2009) Mo (VI) reduction to molybdenum blue by Serratia marcescens strain Dr. Y9. Pol. J. Microbiol. 58: 141-147.

Zeng G.M., Tang L., Shen G.L., Huang G.H., Niu C.G. (2004) Determination of trace chromium (VI) by an inhibitionbased enzyme biosensor incorporating an electropolymerized aniline membrane and ferrocene as electron transfer mediator. Int. J. Environ. Anal. Chem. 84: 761774.

Zhai X.W., Zhang Y.L., Qi Q., Bai Y., Chen X.L., Jin L.J., Ma X.G., Shu R.Z., Yang Z.J. Liu F.J. (2013) Effects of molybdenum on sperm quality and testis oxidative stress. Syst. Biol. Reprod. Med. 59: 251-255.

Zhang Y.L., Liu F.J., Chen X.L., Zhang Z.Q., Shu R.Z., Yu X.L., Zhai X.W., Jin L.J., Ma X.G. Qi Q. et al. (2013) Dual effects of molybdenum on mouse oocyte quality and ovarian oxidative stress. Syst. Biol. Reprod. Med. 59: 312318. 